\title{
Usual gastrointestinal manifestations in an unusual genetic disease
}

\section{Dorina-Monica Pârva* and Daniel Tuculanu}

T,uculanu Medical Center, Department of Gastroenterology, Timisoara, Romania

\section{Introduction}

Hereditary hemorrhagic telangiectasia - HHT (Osler-WeberRendu syndrome) is a heterogeneous autosomal dominant genetic disease, in which cutaneous-mucosal telangiectasia and arterio-venous malformations occur in various organs. From its first description in 1865 (Figure 1), it is frequently mentioned in Textbooks of Hematology, Dermatology or Gastroenterology and is known for its numerous eponymous attributes throughout the time. In medical practice, the disease is rarely encountered, with an incidence of 1-2/100000. Our paper presents a case with multilevel gastrointestinal lesions that we endoscopically highlighted both in white light and in FICE virtual chromoendoscopy.

\section{Case}

A 62-year-old man presented for evaluation of serious iron deficiency anemia, in whose family six other members of four consecutive generations had the same manifestations (Figure 2). In addition, the patient has numerous telangiectasia in the skin and mucous (Figures 3-5), including several level of the digestive tract (oral cavity-Figure 6, esophagus-Figure 7, gastric body-Figure 8, pyloric antrum-Figure 9, duodenal bulb-Figure 10, postbulbar duodenumFigure 11, sigmoid colon-Figure 12 and rectum-Figure 13). The patient has no manifestations of arterio-venous abnormalities in the nervous system, the lungs and the liver, and the CT scan of these organs did not identify vascular malformations (Table 1).

Considering that the patient meets all four international diagnostic criteria (Table 1), we appreciated that the patient suffered from HHT (Rendu-Osler-Weber disease).

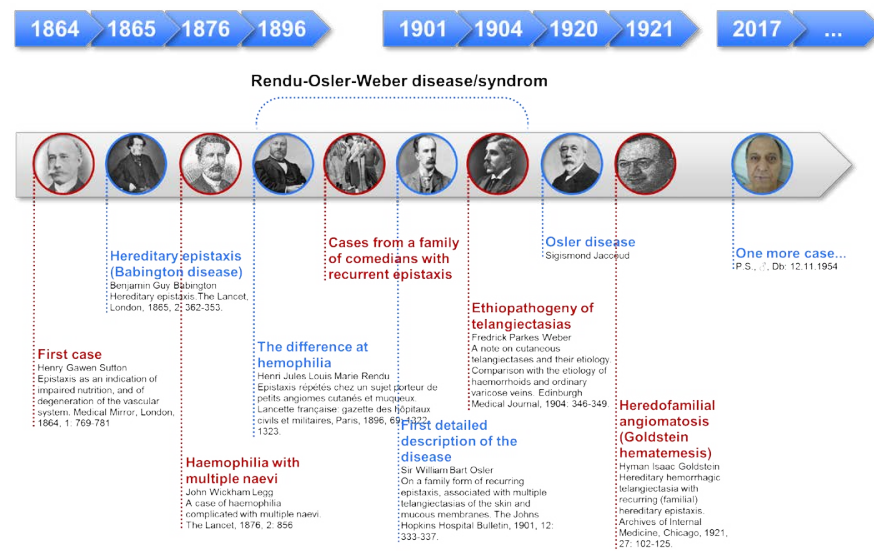

Figure 1. From the first cases described in the literature to our case (male, 63 years old)

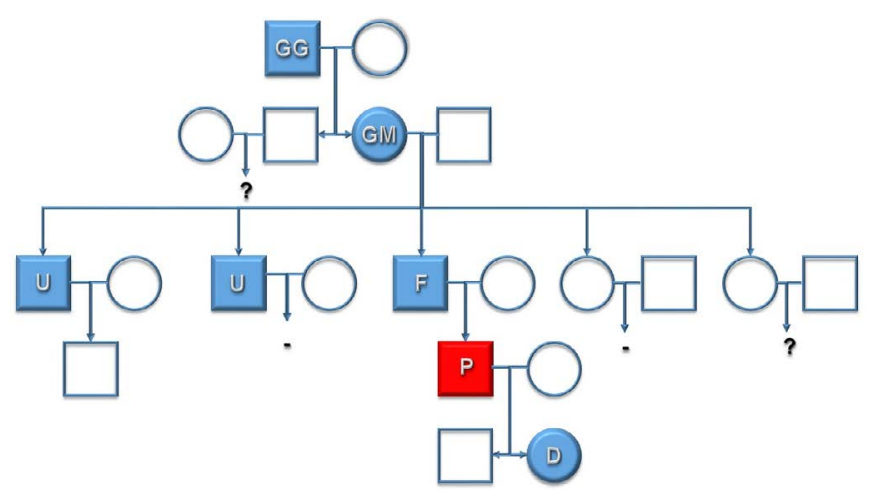

Circle=male, Rectangle $=$ female, $\mathrm{GG}=$ Great-grandfather, $\mathrm{GM}=$ Grandmother, $\mathrm{F}=$ Father $\mathrm{U}=$ Uncle, $\mathrm{P}=$ Patient, $\mathrm{D}=$ Daughter

Figure 2. The genetic investigation revealed in the patient's family 7 cases with autosomal dominant transmission over five generations

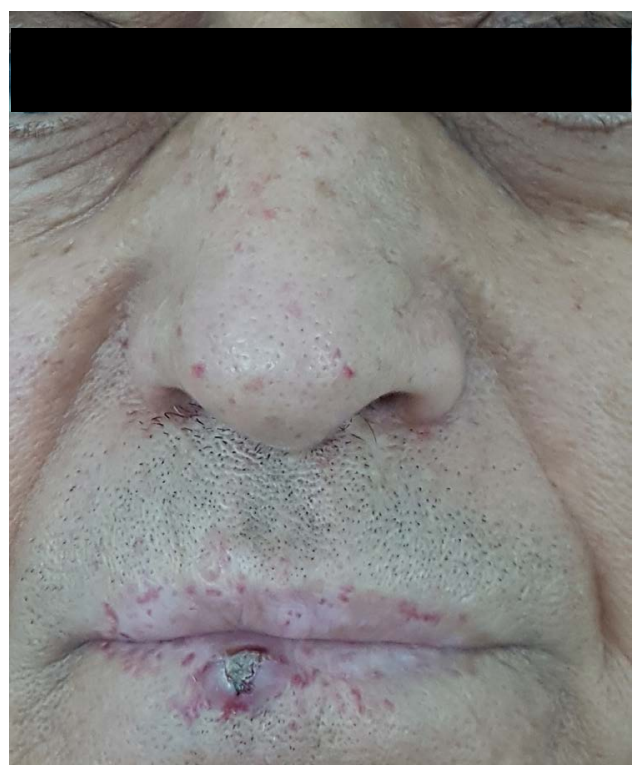

Figure 3. Telangiectasis on the face

*Correspondence to: Dorina-Monica Pârva, Țuculanu Medical Center Department of Gastroenterology, Timisoara, Romania, Tel. 0040-728-955-432 E-mail: dorina_parva@yahoo.com

Received: May 31, 2018; Accepted: June 12, 2018; Published: June 14, 2018 


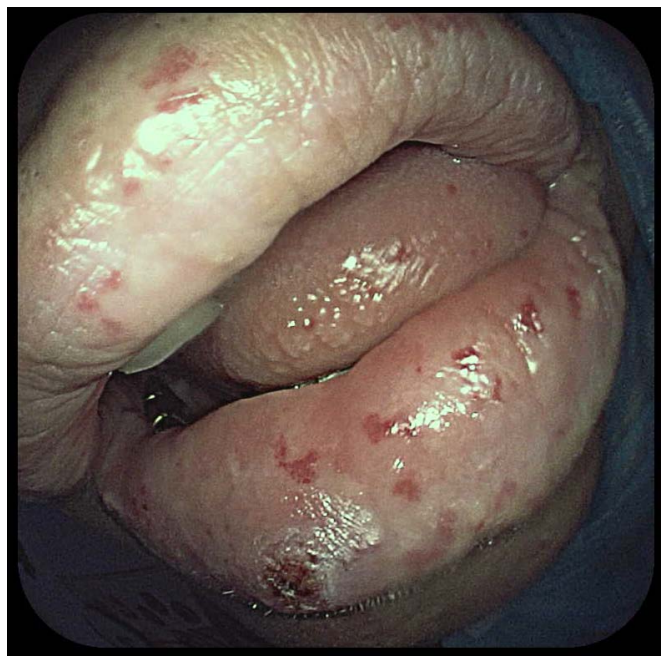

Figure 4. Telangiectasis on the lips and tongue



\section{b}

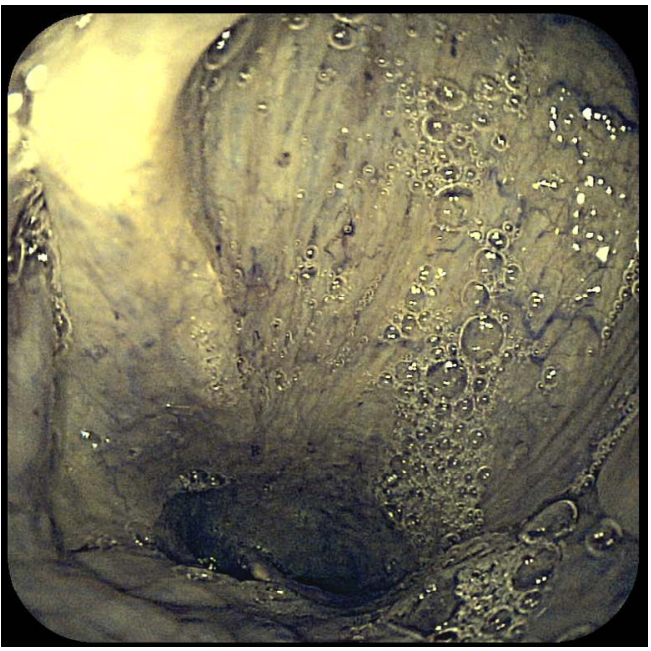

Figure 5. Telangiectasis on the larynx (a-examination in white light; b-examination in FICE spectrum)

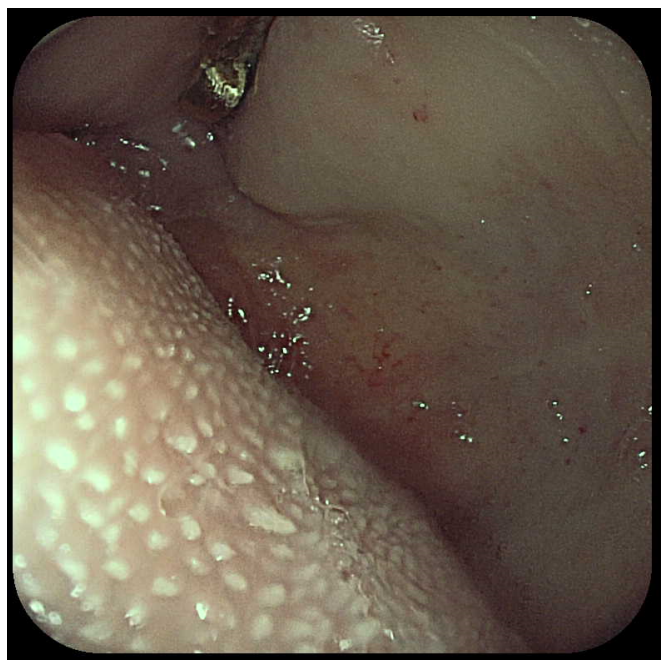

Figure 6. Telangiectasis on the soft palate 

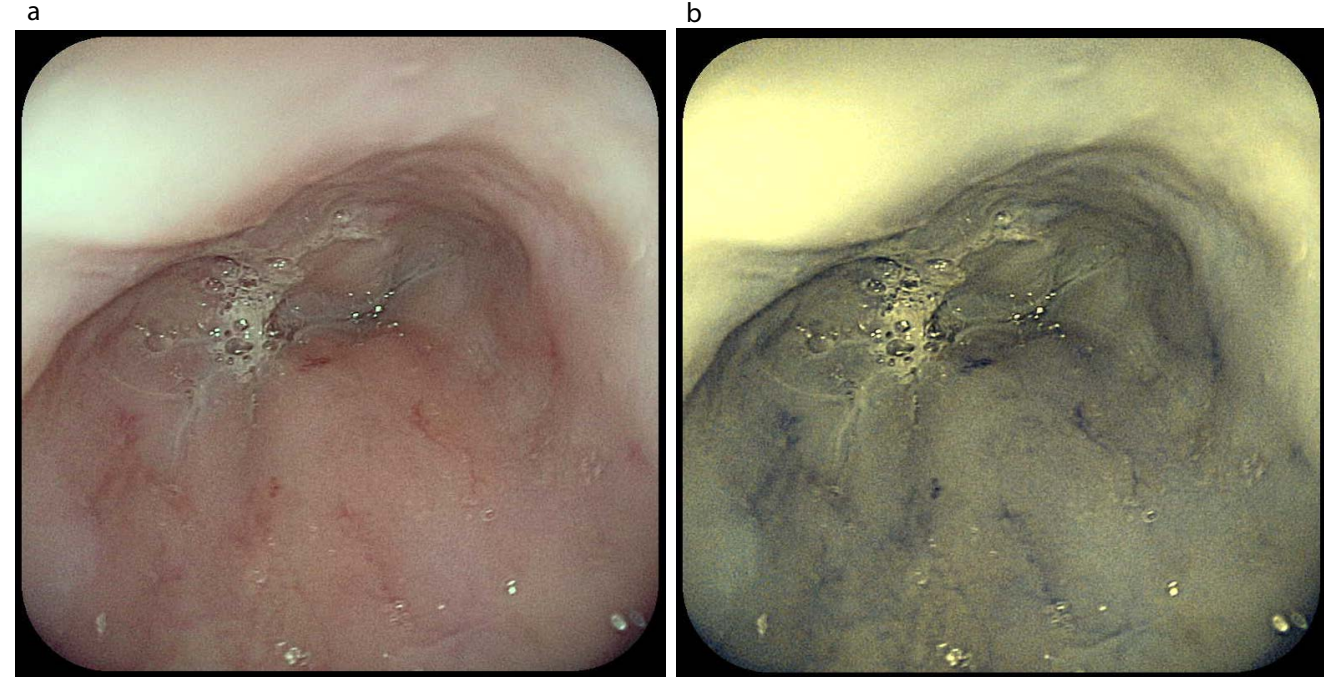

Figure 7. Telangiectasia on the esophagus (a-examination in white light; b-examination in FICE spectrum)

a

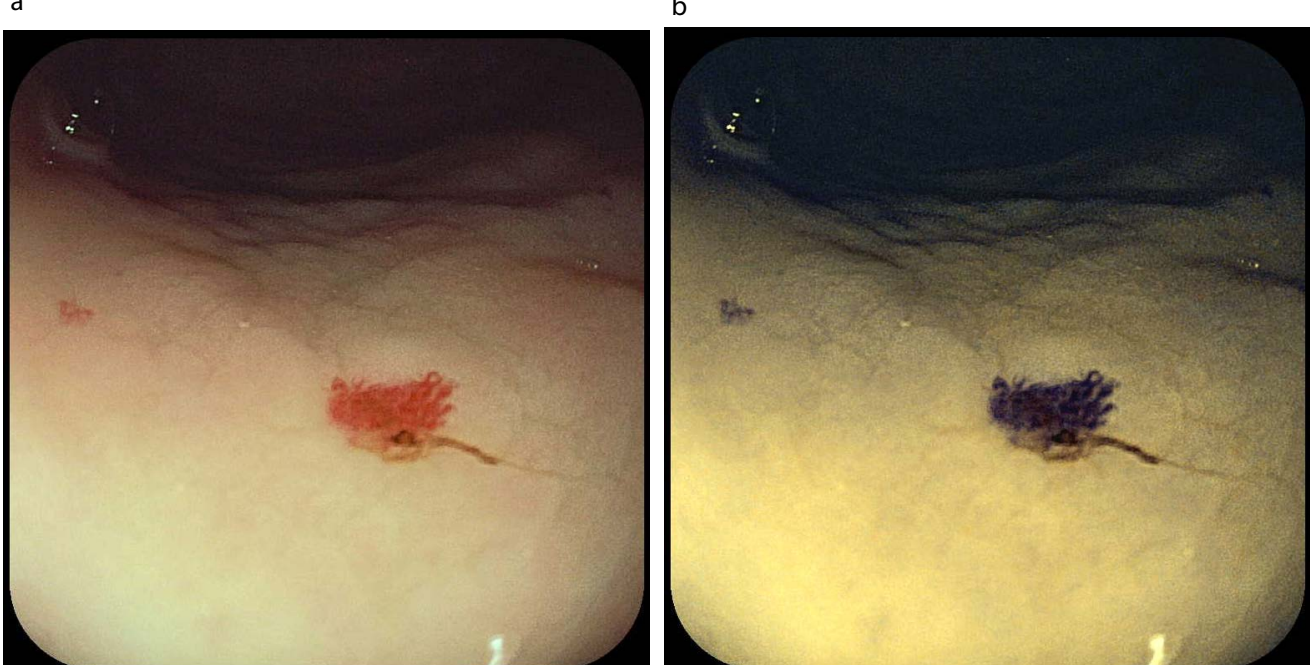

Figure 8. Telangiectasia on the gastric body (a-examination in white light; b-examination in FICE spectrum)

a



Figure 9. Telangiectasia on the pyloric antrum (a-examination in white light; b-examination in FICE spectrum) 
a

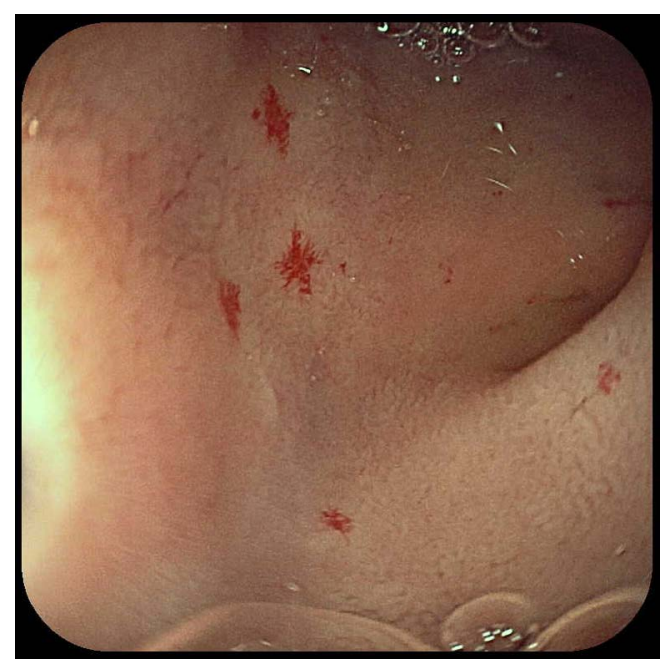

Figure 10. Telangiectasia on the bulbar duodenum (a-examination in white light; b-examination in FICE spectrum)

a

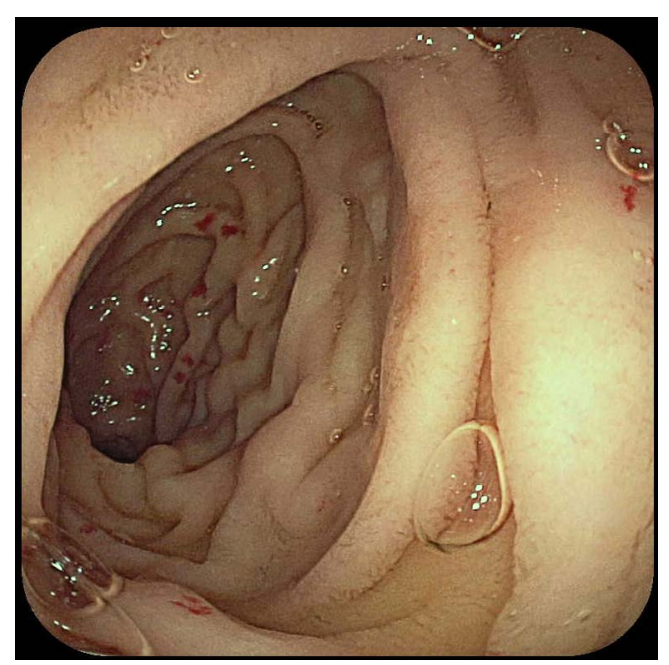

b

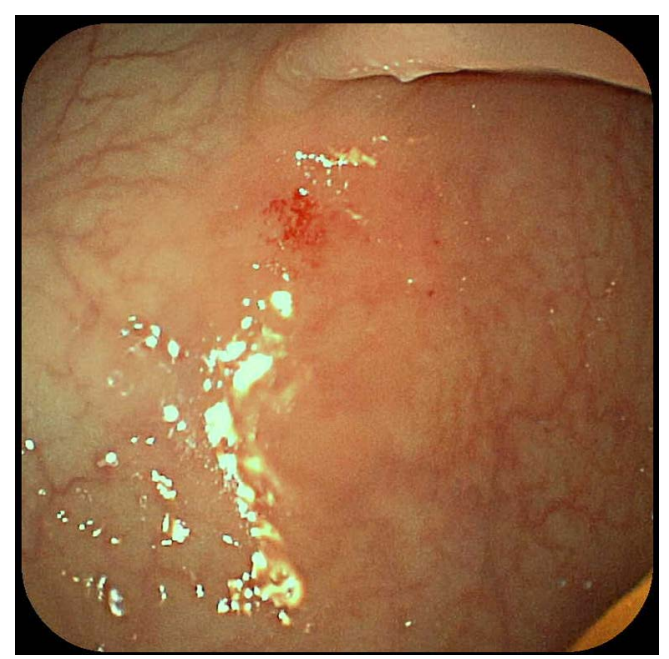

Figure 12. Telangiectasia on the sigmoid colon (a-examination in white light; b-examination in FICE spectrum)

b
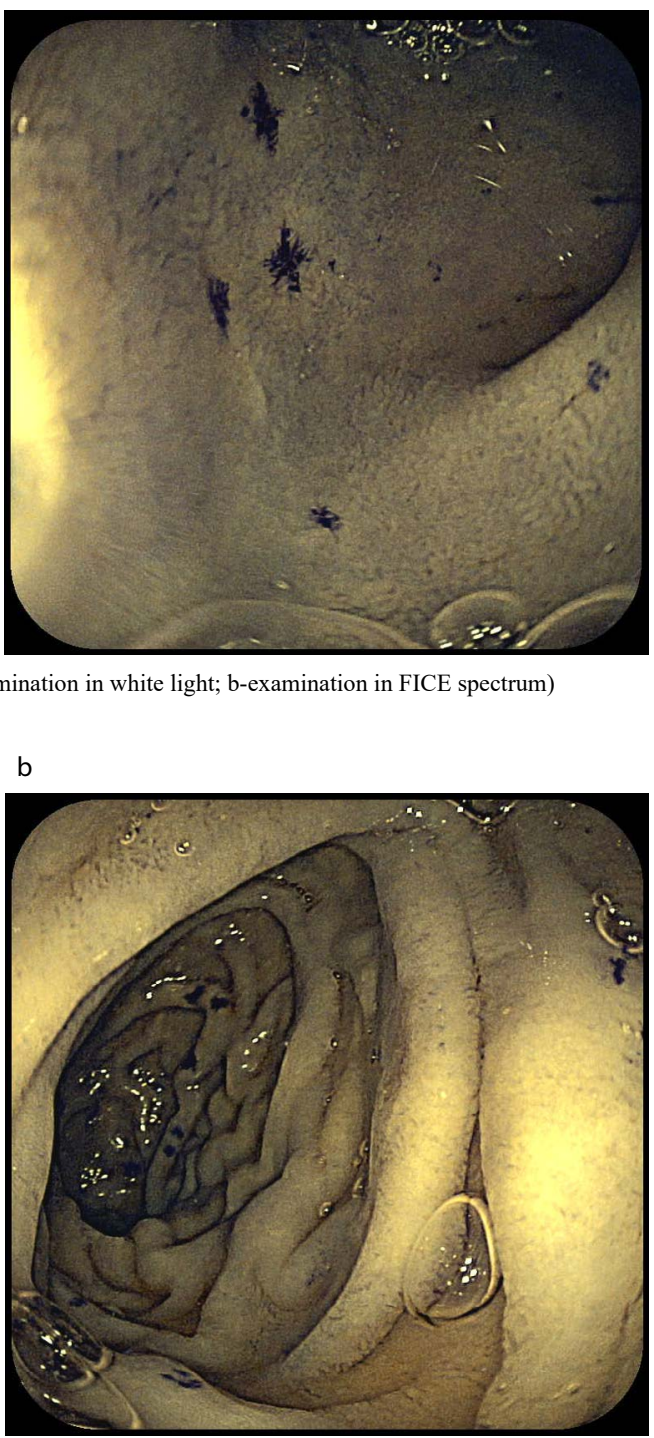

b

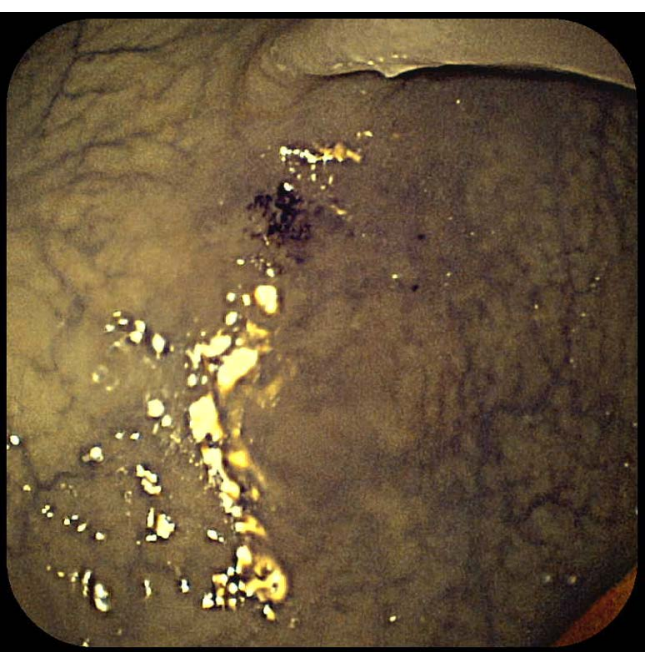


a

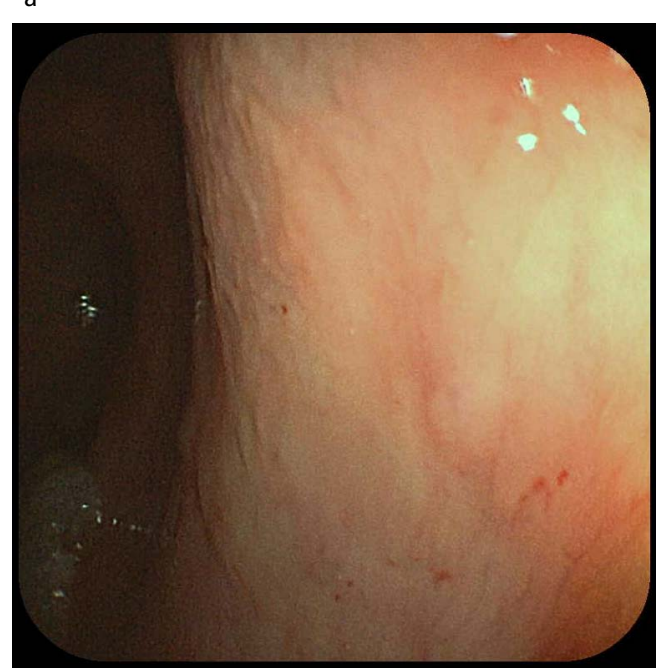

b

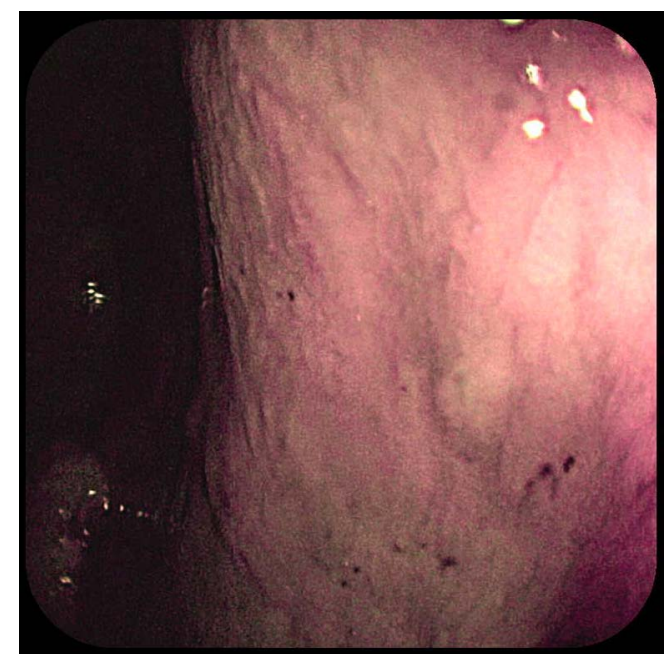

Figure 13. Telangiectasia on the rectum (a-examination in white light; b-examination in FICE spectrum)

Table 1. Diagnostic criteria present at the patient

\begin{tabular}{|c|c|c|c|c|c|}
\hline Criteria & Organs & $+/-$ & Location & Bleeding & Investigations \\
\hline Epistaxis & & $\square$ & & $\begin{array}{c}+++ \\
\text { (spontaneous, recurrent) }\end{array}$ & $\begin{array}{c}\text { Nasal endoscopy revealed } \\
\text { septo-torsional synechiae and } \\
\text { telangiectasia }\end{array}$ \\
\hline \multirow{4}{*}{ Telangiectasia } & & \multirow{4}{*}{$\square$} & Lips & + & \\
\hline & & & Oral cavity & + & \\
\hline & & & Face (periorbitar, nose) & & \\
\hline & & & Auricular pavilion & & \\
\hline \multirow{6}{*}{ Visceral lesions } & Gastro-intestinal & $\square$ & $\begin{array}{l}\text { Pharynx } \\
\text { Esophagus } \\
\text { Stomach } \\
\text { Duodenum } \\
\text { Rectum }\end{array}$ & ++ & $\begin{array}{c}\text { Superior digestive } \\
\text { endoscopy revealed } \\
\text { multiple telangiectasia in } \\
\text { the esophagus, gastric body, } \\
\text { pyloric antrum and bulbar } \\
\text { duodenum and post-bulbar } \\
\text { duodenum. } \\
\text { Lower digestive endoscopy } \\
\text { revealed telangiectasia only } \\
\text { in the rectum. }\end{array}$ \\
\hline & Broncho-pulmonary & $凶$ & & & $\begin{array}{c}\text { Without pulmonary } \\
\text { aneurysmal dilatation or } \\
\text { arterio-venous malformations } \\
\text { (CT) }\end{array}$ \\
\hline & Brain injuries & 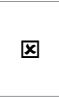 & & & $\begin{array}{c}\text { Without cerebral aneurysmal } \\
\text { dilatation or arterio-venous } \\
\text { malformations (CT) }\end{array}$ \\
\hline & Spinal & $?$ & & & Uninvestigated \\
\hline & Liver damage & ?/囚 & & & Unidentified (Echo) \\
\hline & Arterio-venous malformations & $? / \otimes$ & & & $\begin{array}{l}\text { Unidentified at the brain, lung } \\
\text { and liver }\end{array}$ \\
\hline Family history & & $\square$ & $\begin{array}{c}\text { Great-grandfather GG } \\
\text { Grandmother-GM } \\
\text { Father-F } \\
\text { Uncle-U } \\
\text { Uncle-U } \\
\text { Daughter-D }\end{array}$ & & $\begin{array}{l}\text { Analysis of mutations - the } \\
\text { results obtained were aligned } \\
\text { with the human genome } \\
\text { hg38; the genes tested were: } \\
\text { ACVRL1, ENG, GDF2, } \\
\text { SMAD4, PTEN, PTPN11, } \\
\text { PIK3CA, RASA1, TEK and } \\
\text { AKT1; the sample presents } \\
\text { Class } 3 \text { mutations, which } \\
\text { do not still have clinical } \\
\text { significance. }\end{array}$ \\
\hline
\end{tabular}


With repeated and severe episodes of epistaxis and digestive hemorrhage, the patient has received blood transfusions several times or parenterally treatment with iron products.

\section{Discussion}

The case is interesting because it refers to a very low incidence in the world. Osler-Weber-Rendu disease is a rare genetic condition causing systemic fibrovascular dysplasia, epistaxis and digestive bleeding. Phenotypic variation is extreme ranging from asymptomatic to severely symptomatic, from cases with no or few mucocutaneous lesions to those with diffuse cutaneous telangiectasia. We discuss a case of Osler-Weber-Rendu disease causing diffuse cutaneous telangiectasia, epistaxis, digestive bleeding and iron deficiency anemia.
In addition, there are extensive vascular lesions of the digestive tract that we have been able to observe and record in detail, both in white light and in virtual FICE chromoendoscopy.

The FICE spectrum examination allows for better endoscopic evidence of erythrocytes, mucous and submucosa vessels, due to good penetration and different reflections of green light and blue light. Vascular lesions from various organs occur when the angiogenesis process is disturbed due to multiple genes, depending on which disease is classified into four types: HHT-1 (mutations of ENDOGLIN / ENG), HHT-2 (mutations of ALK-1), HHT-3 (mutations of RASA-1) and HHT-4 (mutations of SMAD-4).

Following the genetic profile of the patient, we determined that it suffers from type 2 disease (with ALK1 gene affection), a clinical form in which there are more frequent hepatic and less pulmonary vascular malformations.

Copyright: (2018 Pârva DM. This is an open-access article distributed under the terms of the Creative Commons Attribution License, which permits unrestricted use, distribution, and reproduction in any medium, provided the original author and source are credited. 